\title{
Exogenous Application of Humic Acid Mitigates Salinity Stress in Maize (Zea mays L.) Plants by Improving some Key Physico-biochemical Attributes
}

\author{
C. KAYA ${ }^{1}$, N.A. AKram ${ }^{2 *}$, M. AshraF ${ }^{3}$ and O. SONMEZ 4 \\ ${ }^{1}$ Department of Soil Science \& Plant Nutrition, Faculty of Agriculture, Harran University, Sanliurfa, Turkey \\ ${ }^{2}$ Department of Botany, Government College University, Faisalabad, 38000, Pakistan \\ ${ }^{3}$ Pakistan Science Foundation, Islamabad, Pakistan \\ ${ }^{4}$ Department of Soil Science \& Plant Nutrition, Faculty of Agriculture, Develi, University of Erciyes, \\ Kayseri, Turkey
}

(Received 22 March 2017; Accepted 4 July 2017;

Communicated by I. Molnár)

\begin{abstract}
Application of salt stress $(100 \mathrm{mM})$ through root growing medium caused a considerable decrease in plant fresh and dry biomass, maximum quantum yield $\left(F_{v} / F_{m}\right)$, chlorophyll contents, leaf water potential, and leaf $\mathrm{Ca}, \mathrm{K}, \mathrm{P}$ and $\mathrm{N}$ concentrations of two maize cultivars (Apex 836 and DK 5783). However, salt-induced increase was observed in leaf osmolality (LO), proline, hydrogen peroxide $\left(\mathrm{H}_{2} \mathrm{O}_{2}\right)$, malondialdehyde (MDA), $\mathrm{Na}^{+}$concentration and activities of enzymatic antioxidants, such as catalase (CAT), peroxidase (POD) and superoxide dismutase (SOD). Of five humic acid (HA) levels used under non-stress and stress conditions in an initial experiment, $100 \mathrm{mg} \mathrm{L}^{-1}$ was chosen for subsequent studies. Exogenous application of humic acid (HA) at the rate of $100 \mathrm{mM}$ as a foliar or pre-sowing seed treatment significantly increased the plant biomass, $F_{v} / F_{m}$, chlorophyll pigments and proline contents, while it considerably reduced the leaf water potential, $\mathrm{H}_{2} \mathrm{O}_{2}$ and MDA contents as well as the activities of all the afore-mentioned enzymatic antioxidants. Of both modes of exogenous treatment, foliar spray was better in improving plant biomass, chlorophyll contents, $\mathrm{LO}$, leaf $\mathrm{Na}^{+}$as well as the accumulation of all nutrients measured, however, in contrast, seed pre-treatment was more effective in altering leaf proline, $\mathrm{H}_{2} \mathrm{O}_{2}$ and MDA contents. Of both maize cultivars, cv. DK 5783 excelled in plant biomass, chlorophyll contents and leaf $\mathrm{N}, \mathrm{Ca}$ and $\mathrm{K}$ concentrations as well as in the activities of all three antioxidant enzymes, whereas cv. Apex 836 was superior in leaf $\mathrm{Na}^{+}$and $\mathrm{P}$ concentrations, $\mathrm{H}_{2} \mathrm{O}_{2}$ and MDA contents. Cv. DK 5783 was comparatively better in salt tolerance as compared to cv. Apex 836. Overall, exogenous application of HA was effective in improving salinity tolerance of maize plants which can be attributed to HA-induced increase in plant biomass, chlorophyll contents, mineral nutrients and activities of key antioxidant enzymes.
\end{abstract}

Keywords: salt stress, humic acid, antioxidants, maize, exogenous application

*Corresponding author; E-mail: nudrataauaf@yahoo.com; Phone: +92419201488 


\section{Introduction}

Salinity is one of the most limiting factors affecting crop growth and yield production of most plants (Salama and Mona 2016). Salinity stress usually induces oxidative stress [generation of reactive oxygen species (ROS)], nutritional imbalance, reduction in cell expansion and division, ion toxicity, hormonal irregulation followed by damages to DNA, RNA and proteins (Zhu 2007; Kaya et al. 2015). Due to over-production of ROS, chlorophyll degradation and lipid peroxidation take place which can increase fluidity and lipid peroxidation of biological membranes. Plants adopt different defensive mechanisms to protect their cells from the oxidative stress caused by ROS. Up-regulation of antioxidant system including enzymatic antioxidants [catalase (CAT), ascorbate peroxidase (APX), superoxide dismutase (SOD) and glutathione reductase (GR)], and non-enzymatic antioxidants such as phenolics, tocopherols, ascorbic acid, glutathione and carotenoids (Sevengor et al. 2011; Shafiq et al. 2015) are included in these mechanisms. Under salt stress, the levels of sodium and chloride generally increase resulting in reduced plant growth and yield (Gama et al. 2007; Memon et al. 2010). Due to salinity-induced specific ion effect or osmotic stress, water uptake capacity of plants also reduces ultimately leading to reduced growth rate (Munns and Tester 2008).

In recent years, the use of fertilizers is increasing day by day. Among these, organic fertilizers are considered as more beneficial (Mehmood et al. 2009) due to their ecofriendly ability and being non-toxic for different plant processes. Remains of animal wastes and organic fertilizers are the major kinds of humus which enhance the fertility of soil and provide balanced nutrition to plants. They are used to produce naturally healthy fruits (Mayi et al. 2014). Humic acids (HAs) are key components of humic substances and hence most dynamic constituents of soil and manure (compost organic matter). Humic acid is known to influence the mechanisms involved in cell respiration, photosynthesis, protein synthesis, nutrient uptake, water uptake and enzyme activities, thereby increasing the yield of crop plants (Mayi et al. 2014; Arjumend et al. 2015). Humic substances can also work against environmental stresses (Mora et al. 2014). For example, under stress conditions, humic substances lower the uptake of toxic elements and enhance the uptake of essential nutrients and minerals (Masciandaro et al. 2002). As compared to absence of HA, the sorption of $\mathrm{Zn}$ by sodium aluminosilicate is improved at lower $\mathrm{pH}$, but it is decreased at higher $\mathrm{pH}$ in the presence of humic acid (Singh et al. 2011; Fasaei 2013).

Maize (Zea mays L.) is one of the most important $\mathrm{C}_{4}$ cereal crops of the world, but it is known to be highly sensitive to saline stress (Chinnusamy et al. 2005; Khodarahmpour et al. 2012). The present study was carried out to evaluate the role of humic acid in improving salinity tolerance of maize plants. Thus, the effect of HA applied as a foliar spray and pre-sowing seed treatment was examined on the growth, chlorophyll machinery, enzymatic and non-enzymatic antioxidants and mineral nutrients in two maize cultivars grown under saline conditions in this study. 


\section{Materials and Methods}

A greenhouse experiment was set-up in a complete randomized block design with three replicates at the Research Station of the University of Harran, Turkey during May to June, 2014. Two maize cultivars, viz. Apex 836 and DK5783, were selected for this study. Ten kilogram of air-dried loamy-clay soil was added to each plastic pot. The texture of the soil used was loamy clay; EC $0.45 \mathrm{dS} \mathrm{m}^{-1}, \mathrm{pH}$ (1:2.5 water, v:v) 7.3, $\mathrm{N}=1.25 \mathrm{~g} \mathrm{~kg}^{-1}$ and $\mathrm{K}=1.40 \mathrm{~g} \mathrm{~kg}^{-1}$. Potassium, $\mathrm{P}$ and $\mathrm{N}$ were added to the soil at the rate of 50, 100 and 120 $\mathrm{mg} \mathrm{kg}^{-1}$ as triple superphosphate, granular urea and potassium sulfate, respectively.

Three seedlings of almost uniform size were maintained in each pot after germination and then transferred all pots to a glasshouse after maintaining relative humidity and mean temperature, $60-70 \%$ and $27 \pm 2{ }^{\circ} \mathrm{C}$, correspondingly. Before the initiation of salt treatment, plants were permitted to establish for seven days. In addition to control [(c), $0 \mathrm{mM}$ $\mathrm{NaCl}$, salt treatment [(s), $100 \mathrm{mM} \mathrm{NaCl} ; 5.85 \mathrm{~g} \mathrm{NaCl} \mathrm{kg}^{-1}$ soil] was applied with irrigation water. The electrical conductivity (EC) of the soil was recorded frequently till the end of the experiment. Of five humic acid levels used under non-stress and saline stress conditions in an initial experiment, $100 \mathrm{mg} \mathrm{L}^{-1}$ was selected for successive studies. The HA (100 $\left.\mathrm{mgL}^{-1}\right)$ was applied as a foliar (f) application and seed soaking (s) to salt-stressed and non-stressed plants. For the seed soaking treatment, the seeds were added in appropriate concentration of HA for one day before sowing. The treatment solutions of humic acid (technical grade, Sigma-Aldrich Chemical Co. Washington, USA) were prepared in distilled water along with $0.1 \%$ Tween-20 (per HA solution) for foliar application treatments. Foliar spray of HA at the rate of $50 \mathrm{~mL}$ per pot was applied after 10 days of seed germination and continued once a week up to day 35 of the start of the experiment. Following growth and physico-biochemical parameters were measured.

\section{Chlorophyll contents}

Leaf sample (one g) was extracted in acetone (90\%), filtered and the aliquot was run on a UV-visible spectrophotometer (Shimadzu UV-1201, Japan) for measuring the absorbance of each sample according to Strain and Svec (1966).

\section{Chlorophyll fluorescence}

Maximal quantum yield $\left(F_{v} / F_{m}\right)$ was measured using a portable chlorophyll fluorimeter (Photosynthesis Yield Analyzer Mini-PAM, Walz, Germany). The data were recorded using previously dark-adapted leaves for $30 \mathrm{~min}$.

\section{Free proline content}

Fresh leaf tissues $(500 \mathrm{mg})$ were extracted in 3\% sulfosalicylic acid $(10 \mathrm{~mL})$. The aliquot $(2 \mathrm{~mL})$ was mixed with acid-ninhydrin $(2 \mathrm{~mL})$ and glacial acetic acid $(2 \mathrm{~mL})$ according to Bates et al. (1973). Then, the mixture was kept in a water bath at $100{ }^{\circ} \mathrm{C}$ for one hour. 
After cooling the samples, four $\mathrm{mL}$ toluene were added to each sample. Then, the mixture was vortexed, and optical density of upper layer (coloured) of each sample read at $520 \mathrm{~nm}$.

\section{Leaf osmolality}

Leaves were kept in a container containing liquid nitrogen and placed at $-80{ }^{\circ} \mathrm{C}$. The samples were extracted after one week and the sap was collected using a syringe. Then, the osmolality of the sap was measured using an osmometer (Cryo-Osmomat 030, Ganotec).

\section{Leaf water potential}

A third fully excised leaf from the top of each plant was separated before sunshine and placed in a pressure chamber (PMS model 600, USA) for measuring leaf water potential.

\section{Electrolyte leakage (EL)}

Fresh leaf $(0.2 \mathrm{~g})$ was sliced into small pieces $(5 \mathrm{~mm})$ and located them in test tubes containing $10 \mathrm{~mL}$ of $\mathrm{dH}_{2} \mathrm{O}$. All test tubes were placed at $32{ }^{\circ} \mathrm{C}$ for two hours using a water bath according to Dionisio-Sese and Tobita (1998). All test tubes were cooled down and the electrical conductivity $\left(\mathrm{EC}_{1}\right)$ of the supernatant was determined. Then, the samples were subjected to an autoclave for $20 \mathrm{~min}$ at $121{ }^{\circ} \mathrm{C}$ and the temperature of the samples was brought down to $25^{\circ} \mathrm{C}$ and then $\mathrm{EC}_{2}$ measured. The following formula was used for determining electrolyte leakage $(\mathrm{EL})=\mathrm{EC}_{1} / \mathrm{EC}_{2} \times 100$.

\section{Antioxidant enzyme assays}

Fresh leaf (500 mg) tissues were ground in Na-P buffer ( $50 \mathrm{mM}$; pH 7.0) containing soluble polyvinyl pyrolidine (1\%). Then, all samples were centrifuged for $12 \mathrm{~min}$ at $20,000 \times g$. The aliquot was stored at $-20{ }^{\circ} \mathrm{C}$ after collecting in autoclaved plastic vials for measuring the activities of antioxidative enzymes such as POD, CAT, and SOD. The activity of CAT was measured according to the protocol of Kraus and Fletcher (1994), that of POD following Chance and Maehly (1955) and SOD according to Beauchamp and Fridovich (1971). The Bradford (1976) method was used to determine the total soluble proteins contents.

\section{Lipid peroxidation}

The method proposed by Weisany et al. (2012) with some alteration was used to assess lipid peroxidation in the leaf samples by determining malondialdehyde contents. 


\section{Hydrogen peroxide contents}

The protocol of Loreto and Velikova (2001) was employed to measure the levels of hydrogen peroxide $\left(\mathrm{H}_{2} \mathrm{O}_{2}\right)$ in the leaf samples of corn plants. Fresh leaf sample $(500 \mathrm{mg})$ was triturated well in $3 \mathrm{~mL}$ trichloroacetic acid (TCA; $1 \% \mathrm{w} / \mathrm{v})$ and then the extract was centrifuged for $10 \mathrm{~min}$ at $10,000 \times g$ at $4{ }^{\circ} \mathrm{C}$. The supernatant $(0.75 \mathrm{~mL})$ was added with $0.75 \mathrm{~mL}$ of potassium phosphate buffer $(10 \mathrm{mM}$; $\mathrm{pH} 7.0)$ and $1.5 \mathrm{~mL}$ of $\mathrm{KI}(1 \mathrm{M})$. The absorbance of the mixture was recorded at $390 \mathrm{~nm}$ and $\mathrm{H}_{2} \mathrm{O}_{2}$ contents expressed as $\mu \mathrm{mol} \mathrm{g}{ }^{-1} \mathrm{FW}$.

\section{Determination of inorganic nutrients}

Oven-dried plant samples were used for determining the concentrations of different inorganic nutrients. The plant materials (dried) were subjected to a muffle furnace for $6 \mathrm{~h}$ at $550{ }^{\circ} \mathrm{C}$. The ash so acquired was added to five $\mathrm{mL}$ hot $\mathrm{HCl}(2 \mathrm{M})$ and elevated the final volume to $50 \mathrm{~mL}$ by adding up distilled water. Potassium $(\mathrm{K})$, sodium $(\mathrm{Na})$, and calcium (Ca) were determined according to Chapman and Pratt (1982). The Vanadate-molybdate method was used to determinethe phosphorus as mentioned in Jackson (1962). Total N in plant samples was appraised using the Kjeldahl apparatus.

\section{Statistical analysis}

The SAS GLM statistical program was employed for working out multivariate analysis of variance (MANOVA) of all parameters measured in the present investigation. The differences between the treatments and cultivars were also worked out using the same program at $P \leq 0.05$.

\section{Results}

Salt stress $(100 \mathrm{mM})$ caused a significant $(P \leq 0.05)$ reduction in the fresh and dry biomass of both maize cultivars (DK 5783 and Apex 836). Foliar application of humic acid (100 $\mathrm{mg} \mathrm{L}^{-1}$ ) through different modes (seed soaking and foliar spray) considerably enhanced the plant fresh and dry biomass of maize plants grown under saline conditions (Table S1*). Foliar application of HA was more efficient as compared to pre-sowing seed treatment in improving plant biomass of both cultivars. Cultivar DK 5783 was better than cv. Apex 836 in plant biomass production under saline stress.

A salt-induced reduction was observed in maximum quantum yield $\left(F_{v} / F_{m}\right)$ of both maize cultivars. Under salinity stress, exogenous application of HA was very effective in altering the $F_{v} / F_{m}$ of maize plants (Table S2). The reaction of both maize cultivars was parallel to both modes of HA application for this leaf fluorescence related attribute.

An increase was observed in the membrane permeability (MP) as shown in increased electrolyte leakages (EL) of both maize cultivars due to exposure to saline stress. The

*Further details about the Electronic Supplementary Material (ESM) can be found at the end of the article. 
foliar spray of HA was effective in lowering the EL under saline conditions as compared to the pre-soaking seed treatment (Table S2).

Salt stress suppressed the chlorophyll contents of both maize cultivars. While, exogenous application of HA was better in enhancing chlorophyll contents than the other exogenous treatment (Table S2). Cultivar DK 5783 was superior to cv. Apex 836 in chlorophyll contents under saline conditions.

A significant decrease (more negative) was observed in the leaf water potential of maize cultivars on exposure to saline stress (Table S3). HA application was effective in lowering the water potential of maize plants. But the reaction of both maize cultivars in this attribute was almost consistent to both modes of HA treatment.

Imposition of salinity stress significantly improved the leaf osmolality (LO) of both maize cultivars. No change was deciphered in LO in both maize cultivars by foliar application of HA under control conditions. However, under salt stress conditions, a considerable reduction was found in LO mainly when HA was applied as a foliar spray (Table S3).

Leaf proline concentration increased when exposed to salinity stress in both maize cultivars. Foliar-applied HA was effective in reducing the proline contents particularly under saline conditions. Of both modes of HA application, foliar application considerably reduced the proline contents under saline stress conditions (Table S3).

A considerable improvement in leaf $\mathrm{Na}^{+}$, but a promising reduction in leaf $\mathrm{N}, \mathrm{P}, \mathrm{Ca}^{2+}$ and $\mathrm{K}^{+}$concentrations was recorded in both maize cultivars under saline conditions. Under salinity, cv. Apex 836 was higher in leaf $\mathrm{Na}^{+}$concentrations, while cv. DK 5783 in leaf $\mathrm{N}, \mathrm{P}, \mathrm{Ca}^{2+}$ and $\mathrm{K}^{+}$concentrations under saline conditions. Humic acid application particularly when applied as a foliar spray was effective in significantly reducing the leaf $\mathrm{Na}^{+}$ concentration, while it improved the accumulation of all the earlier mentioned mineral nutrients (Table S4).

The activities of enzymatic (CAT, POX and SOD) antioxidants improved significantly in both maize cultivars under saline conditions. Foliar application of HA was only effective under saline conditions in reducing the actions of all the above-mentioned antioxidant enzymes in both maize cultivars (Table S5). Of both cultivars, cv. DK 5783 was better in CAT activity, however, the activities of POX and SOD antioxidant enzymes were similar in both maize cultivars under saline conditions.

Due to salinity stress, a significant increase was observed in the $\mathrm{H}_{2} \mathrm{O}_{2}$ and MDA contents in both maize cultivars. A considerable reduction was recorded in $\mathrm{H}_{2} \mathrm{O}_{2}$ and MDA contents due to exogenous application of humic acid. Of both modes, foliar applied HA was more effective in lowering these contents as compared to the seed treatment in both cultivars. $\mathrm{Cv}$. Apex 836 was higher in $\mathrm{H}_{2} \mathrm{O}_{2}$ and MDA contents than the other cultivar under both non-saline and saline regimes (Table S5).

\section{Discussion}

Salinity is the most important limiting environmental constraint that affects growth and productivity of plants. It is evident from different studies that the salinity-induced 
changes in ion accumulation, hormonal regulation, generation of ROS, osmotic stress, and specific ion toxicity in plants ultimately affect plant growth and yield outcomes (Gupta et al. 2014; Zhang et al. 2015). In the present investigation salinity significantly reduced fresh and dry biomass of both maize cultivars while, the deleterious effects of salt stress were suppressed by foliar application of humic acid, because it improved growth of the maize plants under salt stress. The humic acid induced growth improvement could be attributed to the fact that it contains several essential nutrients required for normal plant growth (Cimrin et al. 2010). Quite a few other studies have also shown the beneficial effects of humic acid on the development of different crops grown under stressful environments. For example, Daur and Bakhashwain (2013) reported that application of humic acid at the concentration of $25 \mathrm{~kg} \mathrm{ha}^{-1}$ enhanced quality and growth of maize fodder under a variety of environmental conditions. Similarly, in other crops such as bean (Meganid et al. 2015) and pepper (Cimrin et al. 2010), exogenous application of HA improved their growth under stress conditions which was attributed to better accumulation of essential nutrients particularly $\mathrm{N}, \mathrm{P}$, and $\mathrm{K}$ due to application of HA under salt stress.

Optimum amount of chlorophyll contents is essential for photosynthesis to function normally. However, chlorophyll concentration usually declines under saline stress, which could be attributed to disturbance in rate of chlorophyll biosynthesis, acceleration in chlorophyll degradation, alteration in chlorophyll protein complexes and chloroplast membranes (Ashraf and Harris 2013). A significant decline in chlorophyll pigment is positively correlated with rate of photosynthesis as well as plant growth in different plant species such as sunflower (Akram and Ashraf 2011), alfalfa (Winicov and Seemann 1990), and wheat (Arfan et al. 2007) etc. Reduction in chlorophyll pigments and quantum yield was observed in the salt-stressed maize plants in the present study. Parallel findings were observed in eggplant (Hanachi et al. 2014), wheat (Szopko et al. 2017), cowpea (Taffouo et al. 2009), bean (Turan et al. 2007; Qados 2011; Aydin et al. 2012), and Centaurium erythraea (Siler et al. 2007) under different environmental conditions. Humic acid application was found to be effective in improving chlorophyll content in the maize plants in the present investigation. Quite analogous to our findings, Aydin et al. (2012) also reported an increase in chlorophyll content in humic acid treated bean plants under saline stress.

Under salinity stress, osmotic potential of leaves lower than its surroundings is a means to tolerate salt stress (Qados 2011). Improvement in leaf osmolality (more negative osmotic potential) was found in both maize cultivars in the present study. While, foliar-applied HA particularly increased leaf osmolality in both maize cultivars. Leaf water potential of both maize cultivars was suppressed under salinity, but exogenous application (foliar applied) of humic acid, particularly increased leaf water potential in the present study. Similar to our findings, reduction in water potential was also observed in wheat (Farouk 2011) and safflower (Siddiqi and Ashraf 2008) plants exposed to saline stress.

Membrane permeability of both maize cultivars was increased as shown an increased electrolyte leakage (EL) by salinity, while foliar application of HA reduced EL under saline conditions as earlier reported by Tuna et al. (2007) in tomato plants exposed to saline stress. Similarly, Osman and Rady (2014) also reported that the membrane permeability 
was improved by HA application in eggplant. In contrast to our results, Jamil et al. (2012) observed that membrane permeability decreased in sugar beet plants due to HA application.

Accumulation of proline under stress conditions is an indicator of cell injury (Aydin et al. 2012; Bakry et al. 2014). However, proline being a compatible solute is believed to play an important function in stress tolerance. Salt stress improved proline contents in both maize cultivars in the present study, but of both modes, foliar applied HA reduced proline content in plants exposed to salinity stress. In another study with bean plants, Bakry et al. (2014) observed that salinity improved proline contents while humic acid application suppressed it under stress conditions. The authors further suggested that some specific salt-induced proteins were expressed due to proline that could be involved in improvement of plant growth under saline stress.

Nutrient uptake by roots is essential for maintaining plant growth and it was thought that $\mathrm{Ca}$ in soil helps in reducing the uptake of $\mathrm{Na}$ and mitigates the adverse effects of salinity on plants (Mohamed 2012). Humic acid is believed to be important for the uptake and transportation of nutrients in plants (Aydin et al. 2012). In the present study, it was observed that salinity increased $\mathrm{Na}$ accumulation while decreased that of $\mathrm{P}, \mathrm{K}, \mathrm{Ca}$ and $\mathrm{N}$ in maize plants. While, humic acid decreased the accumulation of $\mathrm{Na}$ and improved that of the other nutrients. Uptake of nutrients has also been shown to have been improved by humic acid application in corn (Khaled and Fawy 2011; Mohamed 2012), and cotton (Rady et al. 2016) under saline conditions. Selim et al. (2012) observed that humic acid application improved growth of broccoli due to uptake of nutrients like K, Zn, Mn, P and N. It has been speculated that surface tension of water can be reduced by humic acid which in turn can enhance the uptake and effectiveness of nutrients (Rady et al. 2016).

Activities of enzymatic antioxidants (CAT, POD and SOD) are linked to plant salinity tolerance because these antioxidants help detoxify the salt generated ROS (Ashraf 2009). In the present study, the activities of enzymatic antioxidants such as CAT, POD and SOD increased in the maize plants under salt stress. While, exogenously-applied HA suppressed the activities of these enzymes under salt stress conditions. In contrast to our results, Kiran et al. (2014) found that exogenously applied humic acid was effective in improving stress tolerance in eggplant by enhancing enzymatic antioxidants' activity under heavy metal stress. Aminifard et al. (2012) reported that HA application (250 $\left.\mathrm{mg} \mathrm{kg}^{-1}\right)$ treatment significantly improved the antioxidant activity, total flavonoid, capsaicin, lycopene, and $\beta$-carotene in the fruits of hot pepper under field conditions. In another study with cucumber plants grown under field conditions, Karakurt et al. (2015) found that the foliar as well as soil application of HA improved the fruit quality of cucumber and they attributed this improvement to HA-induced antioxidant potential particularly xanthophyll, total phenolics and $\beta$-carotene.

In the present study, $\mathrm{H}_{2} \mathrm{O}_{2}$ and MDA contents increased in both maize cultivars under salinity stress. Foliar-applied HA was more useful in suppressing $\mathrm{H}_{2} \mathrm{O}_{2}$ and MDA in the maize plants compared to the seed treatment under saline conditions. Malondialdehyde (MDA) is known to be an indicator of membrane damage caused due to ROS under stress conditions (Liu et al. 2013; Shafiq et al. 2015). While working with canola Hasanuzza- 
man et al. (2012) and wheat, Hasanuzzaman et al. (2011) reported that salinity stress enhanced $\mathrm{H}_{2} \mathrm{O}_{2}$ contents in the plants. Analogous to our results, MDA and $\mathrm{H}_{2} \mathrm{O}_{2}$ contents were also reduced in grapes (Kesba and El-Beltagi 2012) due to humic acid application.

Overall, salt stress significantly reduced plant fresh and dry biomass, quantum yield, chlorophyll contents and leaf water potential, while it increased leaf osmolality, proline, MDA, $\mathrm{H}_{2} \mathrm{O}_{2}$ and activities of enzymatic antioxidants. Foliar-applied HA reduced the activities of antioxidant enzymes, Na, LO, and WP, but it enhanced quantum yield and chlorophyll contents. Presowing treatment with HA was effective in improving plant biomass and proline contents and lowering MDA and $\mathrm{H}_{2} \mathrm{O}_{2}$ contents. Of both cultivars, cv. Apex 836 was higher in $\mathrm{Na}, \mathrm{P}, \mathrm{MDA}$ and $\mathrm{H}_{2} \mathrm{O}_{2}$, and cv. DK 5783 in plant biomass, chlorophyll pigments, $\mathrm{N}, \mathrm{Ca}, \mathrm{K}$ and activities of antioxidant enzymes. The response of both cultivars was similar to other studied attributes in the maize cultivars under stress conditions.

\section{Acknowledgement}

This research was supported by the Scientific and Technical Research Council of Turkey (TUBITAK-TOVAG-112O375).

\section{References}

Akram, N.A., Ashraf, M. 2011. Improvement in growth, chlorophyll pigments and photosynthetic performance in salt-stressed plants of sunflower (Helianthus annuus L.) by foliar application of 5-aminolevulinic acid. Agrochimica 55:94-104.

Aminifard, M.H., Aroiee, H., Ameri, A., Fatem, H. 2012. Effect of plant density and nitrogen fertilizer on growth, yield and fruit quality of sweet pepper (Capsicum annuum L.). Afr. J. Agric. Res. 7:859-866.

Arfan, M., Athar, H.R., Ashraf, M. 2007. Does exogenous application of salicylic acid through the rooting medium modulate growth and photosynthetic capacity in two differently adapted spring wheat cultivars under salt stress? J. Plant Physiol. 164:685-694.

Arjumend, T., Abbasi, M.K., Rafique, E. 2015. Effects of lignite-derived humic acid on some selected soil properties, growth and nutrient uptake of wheat (Triticum aestivum L.) grown under greenhouse conditions. Pak. J. Bot. 47:2231-2238.

Ashraf, M. 2009. Biotechnological approach of improving plant salt tolerance using antioxidants as markers. Biotechnol. Adv. 27:84-93.

Ashraf, M., Harris, P.J.C. 2013. Photosynthesis under stressful environments: An overview. Photosynthetica 51:163-190.

Aydin, A., Kant, C., Tyran, M. 2012. Humic acid application alleviate salinity stress of bean (Phaseolus vulgaris L.) plants decreasing membrane leakage. Afric. J. Agric. Res. 7:1073-1086.

Bakry, B.A., Taha, M.H., Abdelgawad, Z.A., Abdallah, M.M.S. 2014. The role of humic acid and proline on growth, chemical constituents and yield quantity and quality of three flax cultivars grown under saline soil conditions. Agric. Sci. 5:1566-1575.

Bates, L.S., Waldren, R.P., Teare, I.D. 1973. Rapid determination of free proline for water-stress studies. Plant Soil 39:205-207.

Beauchamp, C., Fridovich, I. 1971. Superoxide dismutase: improved assays and an assay applicable to acrylamide gels. Anal. Biochem. 44:276-287.

Bradford, M.M. 1976. A rapid and sensitive method for the quantitation of microgram quantities of protein utilizing the principle of protein-dye binding. Anal. Biochem. 72:248-254.

Chance, M., Maehly, A.C. 1955. Assay of catalases and peroxidases. Methods Enzymol. 2:764-817. 
Chapman, H.D., Pratt, P.F. 1982. Methods of Plant Analysis. I. Methods of Analysis for Soils, Plants and Water. Chapman Publishers. Riverside, CA, USA.

Chinnusamy, V., Jagendorf, A., Zhu, J.K. 2005. Understanding and improving salt tolerance in plants. Crop Sci. 45:437-448.

Cimrin, K.M., Türkmen, O., Turan, M., Tuncer, B. 2010. Phosphorus and humic acid application alleviate salinity stress of pepper seedlings. Afr. J. Biotechnol. 9:5845-5851.

Daur, I., Bakhashwain, A.A. 2013. Effect of humic acid on growth and quality of maize fodder production. Pak. J. Bot. 45:21-25.

Dionisio-Sese, M.L., Tobita, S. 1998. Antioxidant responses of rice seedlings to salinity stress. Plant Sci. 135:1-9.

Farouk, S. 2011. Osmotic adjustment in wheat flag leaf in relation to flag leaf area and grain yield per plant. J. Stress Physiol. Biochem. 7:117-138.

Fasaei, R.G. 2013. Influence of foliar application of salicylic acid and soil application of humic materials on cucumber and chickpea grown on a nutrient deficient soil. Int. J. Agric. Crop Sci. 5:2639-2644.

Gama, P.B.S., Inanaga, S., Tanaka, K., Nakazawa, R. 2007. Physiological response of common bean (Phaseolus vulgaris L.) seedlings to salinity stress. Afr. J. Biotechnol. 6:79-88.

Gupta, K., Jha, B., Agarwal, P.K. 2014. A dehydration-responsive element binding (DREB) transcription factor from the succulent halophyte Salicornia brachiate enhances abiotic stress tolerance in transgenic tobacco. Marine Biotechnol. 16:657-673.

Hanachi, S., Van Labeke, M.C., Mehouachi, T. 2014. Application of chlorophyll fluorescence to screen eggplant (Solanum melangenum L.) cultivars for salt tolerance. Photosynthetica 52:57-62.

Hasanuzzaman, M., Hossain, M.A., Fujita, M. 2011. Nitric oxide modulates antioxidant defense and the methylglyoxal detoxification system and reduces salinity-induced damage of wheat seedlings. Plant Biotechnol. Rep. 5:353-365.

Hasanuzzaman, M., Hossain, M.A., Fujita, M. 2012. Exogenous selenium pretreatment protects rapeseed seedlings from cadmium-induced oxidative stress by upregulating antioxidant defense and methylglyoxal detoxification systems. Biol. Trace Elem. Res. 149:248-261.

Jackson, M.L. 1962. Soil Chemical Analysis, Prentice Hall. Englewood Cliffs. New York, USA.

Jamil, M., Bashir, S., Anwar, S., Bibi, S., Bangash, A., Farman U., Shikrha, E. 2012. Effect of salinity on physiological and biochemical characteristics of different varieties of rice. Pak. J. Bot. 44:7-13.

Karakurt, Y., Ozdamar-Unlu, H., Unlu, H., Tonguc, M. 2015. Antioxidant compounds and activity in cucumber fruit in response to foliar and soil humic acid application. Eur. J. Hort. Sci. 80:76-80.

Kaya, C., Ashraf, M., Sonmez, O. 2015. Promotive effect of exogenously applied thiourea on key physiological parameters and oxidative defense mechanism in salt-stressed Zea mays L. plants. Turk. J. Bot. 39:786-795.

Kesba, H.H., El-Beltagi, H.S. 2012. Biochemical changes in grape rootstocks resulted from humic acid treatments in relation to nematode infection. Asian Pacific J. Tropical Biomedicine 2:287-293.

Khaled, H., Fawy, H.A. 2011. Effect of different levels of humic acids on the nutrient content, plant growth and soil properties under conditions of salinity. Soil Water Res. 6:21-29.

Khodarahmpour, Z., Ifar, M., Motamedi, M. 2012. Effects of $\mathrm{NaCl}$ salinity on maize (Zea mays L.) at germination and early seedling stage. Afr. J. Biotechnol. 11:298-304.

Kiran, S., Ozkay, F., Kusvuran, S., Ellialtioglu, S.S. 2014. The effect of humic acid applications on some morphological, physiological and biochemical characteristics of eggplants irrigated with water contained heavy metals in high concentration. Turk. J. Agric. Food Sci. Technol. 2:280-288.

Kraus, T.E., Fletcher, R.A. 1994. Paclobutrazol protects wheat seedlings from heat and paraquat injury. Is detoxification of active oxygen involved? Plant Cell Physiol. 35:45-52.

Liu, X.M., Nguyen, X.C., Kim, K.E., Han, H.J., Yoo, J., Lee, K., Kim, M.C., Yun, D.J., Chung, W.S. 2013. Phosphorylation of the zinc finger transcriptional regulator ZAT6 by MPK6 regulates Arabidopsis seed germination under salt and osmotic stress. Biochem. Biophys. Res. Commun. 430:1054-1059.

Loreto, F., Velikova, V. 2001. Isoprene produced by leaves protects the photosynthetic apparatus against ozone damage, quenches ozone products, and reduces lipid peroxidation of cellular membranes. Plant Physiol. 127:1781-1787. 
Masciandaro, G., Ceccanti, B., Ronchi, V., Benedicto, S., Howard, L. 2002. Humic substances to reduce salt effect on plant germination and growth. Commun. Soil Sci. Plant Anal. 33:365-378.

Mayi, A.A., Ibrahim, Z.R., Abdurrahman, A.S. 2014. Effect of foliar spray of humic acid, ascorbic acid, cultivars and their interactions on growth of olive (Olea europea L.) transplants cvs. Khithairy and Sorany. J. Agric. Vet. Sci. 7:18-30.

Meganid, A.S., Al-Zahrani, H.S., El-Metwally, S.M. 2015. Effect of humic acid application on growth and chlorophyll contents of common bean plants (Phaseolus vulgaris L.) under salinity stress conditions. Int. J. Innov. Res. Sci., Engineer. Technol. 4:2652-2660.

Mehmood, E., Kausar, R., Akram, M., Shahzad, S.M. 2009. Is boron required to improve rice growth and yield in saline environment? Pak. J. Bot. 41:1339-1350.

Memon, S.A., Hou, X., Wang, L.J. 2010. Morphological analysis of salt stress response of pakchoi. Electronic J. Environ. Agric. Food Chem. 9:248-254.

Mohamed, W.H. 2012. Effects of humic acid and calcium forms on dry weight and nutrient uptake of maize plant under saline condition. Aust. J. Basic Appl. Sci. 6:597-604.

Mora, V., Olaetxea, M., Bacaicoa, E., Baigorri, R., Fuentes, M., Zamarreno, A.M., Garcia-Mina, J.M. 2014. Abiotic stress tolerance in plants: exploring the role of nitric oxide and humic substances. In: Lamattina, L., Polacco, J.C. (eds), Nitric Oxide in Plants: Metabolism and Role in Stress Physiology. Springer. Amsterdam, The Netherlands. pp. 243-264.

Munns, R., Tester, M. 2008. Mechanisms of salinity tolerance. Annu. Rev. Plant Biol. 59:651-681.

Osman, A.S.H., Rady, M.M. 2014. Effect of humic acid as an additive to growing media to enhance the production of eggplant and tomato transplants. J. Hort. Sci. Biotechnol. 89:237-244.

Qados, A.M.S.A. 2011. Effect of salt stress on plant growth and metabolism of bean plant Vicia faba (L.). J. Saudi Soc. Agric. Sci. 10:7-15.

Rady, M.M., Abd El-Mageed, T.A., Abdurrahman, H.A., Mahdi, A.H. 2016. Humic acid application improves field performance of cotton (Gossypium barbadense L.) under saline conditions. J. Animal Plant Sci. 26:487-493.

Salama, A.M., Mona, A.E. 2016. Morphological and anatomical studies of grafting cucumber onto three different wild rootstocks grown under salinity in nutrient film technique system. Int. J. Adv. Res. 4:583-595.

Selim, E.M., Shaymaa, I.S., Faiz, F.A., El-Neklawy, A.S. 2012. Interactive effects of humic acid and water stress on chlorophyll and mineral nutrient contents of potato plants. J. Appl. Sci. Res. 8:531-537.

Sevengor, S., Yasar, F., Kusvuran, S., Ellialtioglu, S. 2011. The effect of salt stress on growth, chlorophyll content, lipid peroxidation and antioxidative enzymes of pumpkin seedling. Afr. J. Agric. Res. 6:49204924.

Shafiq, S., Akram, N.A., Ashraf, M. 2015. Does exogenously-applied trehalose alter oxidative defense system in the edible part of radish (Raphanus sativus L.) under water-deficit conditions? Sci. Hort. 85:68-75.

Siddiqi, E.H., Ashraf, M. 2008. Can leaf water relation parameters be used as selection criteria for salt tolerance in safflower (Carthamus tinctorius L.)? Pak. J. Bot. 40:221-228.

Siler, B., Misic, D., Filipovic, B., Popovic, Z., Cvetic, T., Mijovic, A. 2007. Effects of salinity on in vitro growth and photosynthesis of common centaury (Centaurium erythraea Rafn.). Archives Biol. Sci. 59:129-134.

Singh, S.N., Singh, A.K., Singh, S.C., Sharma, M.L., Kumar, R. 2011. Enhancing sugarcane (Saccharum spp. hybrid) productivity by integrating organic, inorganic and biological sources of $\mathrm{N}$ in sub-tropical India. Indian J. Sugar Technol. 26:14-15.

Strain, H.H., Svec, W.A. 1966. Extraction, separation, estimation and isolation of chlorophylls. In: Vernon, L.P., Seely, G.R. (eds), The Chlorophylls. Academic Press. New York, USA. pp. 21-66.

Szopko, D., Darkó, E., Molnár, I., Kruppa, K., Háló, B., Vojtkó, A., Molnár-Láng, M., Dulai, S. 2017. Photosynthetic responses of a wheat (Asakaze)-barley (Manas) $7 \mathrm{H}$ addition line to salt stress. Photosynthetica 55:317-328.

Taffouo, V.D., Kouamou, J.K., Ngalangue, L.M.T., Ndjeudji, B.A.N., Akoa, A. 2009. Effects of salinity stress on growth, ions partitioning and yield of some cowpea (Vignaun giuculata L., Walp) cultivars. Int. J. Bot. 5:135-143. 
Tuna, A.L., Kaya, C., Ashraf, M., Altunlu, H., Yokas, I., Yagmur, B. 2007. The effects of calcium sulphate on growth, membrane stability and nutrient uptake of tomato plants grown under salt stress. Environ. Exp. Bot. 59:173-178.

Turan, M.A., Kalkat, V., Taban, S. 2007. Salinity-induced stomatal resistance, proline, chlorophyll and ion concentrations of bean. Int. J. Agric. Res. 2:483-488.

Weisany, W., Sohrabi, Y., Heidari, G., Siosemardeh, A., Ghassemi-Golezani, K. 2012. Changes in antioxidant enzymes activity and plant performance by salinity stress and zinc application in soybean (Glycine max L.). Plant Omics J. 5:60-67.

Winicov, I., Seemann, J.R. 1990. Expression of genes for photosynthesis and the relationship to salt tolerance of alfalfa (Medicago sativa) cells. Plant Cell Physiol. 31:1155-1161.

Zhang, Y., Wang, Y., Taylor, J.L., Jiang, Z., Zhang, S., Mei, F., Wu, Y., Wu, P., Ni, J. 2015. Aequorin-based luminescence imaging reveals differential calcium signalling responses to salt and reactive oxygen species in rice roots. J. Exp. Bot. 66:2535-2545.

Zhu, J.K. 2007. Plant Salt Stress. John Wiley \& Sons, Ltd. University of Arizona, Tucson, Arizona, USA.

\section{Electronic Supplementary Material (ESM)}

Electronic Supplementary Material (ESM) associated with this article can be found at the website of CRC at http://www.akademiai.com/content/120427/

Electronic Supplementary Table S1. Fresh and dry weights of two cultivars of maize grown in salt with or without humic acid $\left(\mathrm{mg} \mathrm{L}^{-1}\right)$ applied through different modes

Electronic Supplementary Table S2. Maximum fluorescence yield $\left(F_{v} / F_{m}\right)$, membrane leakage (ML) and total chlorophyll ( $\left.\mathrm{mg} \mathrm{kg}^{-1} \mathrm{Fw}\right)$ of two cultivars of maize grown in salt with or without humic acid (mg L $\left.{ }^{-1}\right)$ applied through different modes

Electronic Supplementary Table S3. Leaf water potential ( $\Psi 1$ : MPa), leaf osmolality (LO, Osmol $\left.\mathrm{kg}^{-1}\right)$ and proline (pro, $\mathrm{mmol} \mathrm{g}^{-1} \mathrm{FW}$ ) of two cultivars of maize grown in salt with or without humic acid (mg L $\mathrm{m}^{-1}$ ) applied through different modes

Electronic Supplementary Table S4. Concentrations of different inorganic elements $\left(\mathrm{mmol} \mathrm{kg}^{-1} \mathrm{DW}\right)$ in the leaves of two cultivars of maize grown in salt with or without humic acid $\left(\mathrm{mg} \mathrm{L}^{-1}\right)$ applied through different modes

Electronic Supplementary Table S5. Activities/concentrations of superoxide dismutase (SOD: Unit/mg protein/ $\mathrm{min}$ ), catalase (CAT: Unit $\times 100 / \mathrm{mg}$ protein), peroxidase (POX: $\Delta \mathrm{A}_{470} / \mathrm{min} / \mathrm{mg}$ protein), hydrogen peroxide $\left(\mathrm{H}_{2} \mathrm{O}_{2}: \mu \mathrm{mol} \mathrm{g} \mathrm{g}^{-1} \mathrm{Fw}\right)$ and malondialdehyde (MDA: $\left.\mathrm{nmol} \mathrm{g}^{-1} \mathrm{FW}\right)$ in the leaves of two cultivars of maize grown in salt with or without humic acid $\left(\mathrm{mg} \mathrm{L}^{-1}\right)$ applied through different modes 